rarely described..$^{3-9}$ Hypothyroidism, as was present in our second patient, has also been described in association with watermelon stomach. ${ }^{10}$

Our patients represent cases in which gastrointestinal bleeding secondary to the watermelon stomach was an early manifestation of their scleroderma. Similarly, Rosekrans, et al described one patient in whom anaemia secondary to bleeding from the watermelon stomach predated the diagnosis of scleroderma. ${ }^{4}$ Most cases of watermelon stomach, however, have been reported to occur in those who already have well established scleroderma. ${ }^{39}$

Bleeding from the watermelon stomach and activity of scleroderma did not necessarily parallel each other. In the first case recurrent bleeding from the watermelon stomach occurred when other manifestations of scleroderma were quiescent. In the second case the manifestations of the watermelon stomach and the activity of the scleroderma progressed concurrently. Progression of scleroderma and concomitant bleeding from the watermelon stomach have been reported, ${ }^{5}$ but it is not known whether this is always the case. Further cases will need to be examined to determine the relation between the activity of the watermelon stomach and progression of the scleroderma.

Doctors should be aware that watermelon stomach may be an early manifestation of scleroderma, and bleeding from the watermelon stomach may occur any time during the course of disease.

LAURA D CARBONE* KEVIN M MCKOWN* R JAMES ST HILAIRE + PATRICK J DEAN STANLEY B KAPLAN Department of Medicine *Division of Rheumatology, $\dagger$ Division of Gastroenterology $\ddagger$ Department of Pathology, University of Tennessee at Memphis

EDWARD L CATTAU JR Memphis Gastroenterology Group Correspondence to: Dr Laura D Carbone,
University of Tennessee at Memphis, 956 Court University of Tennessee at Memphis, 956 Court Avenue,

1 Gostout C J, Viggiano T R, Ahlquist D A, Wang K K, Larson M V, Balm R. The clinical and endoscopic spectrum of the watermelon stomach. $\mathcal{f}$ Clin Gastroenterol 1992; 15: 256-63.

2 Suit P F, Petras R E, Bauer T W, Petrini J L. Gastric antral vascular ectasia: a histologic and morphometric study of "the watermelon stomach". Am $\mathcal{f}$ Surg Pathol 1987; 11: 750-7.

3 Scolapio J S, Matteson E L. The watermelon stomach in scleroderma. Arthritis Rheum 1993; 36: 724-5.

4 Rosekrans P C M, de Rooy D J, Bosman F T, Eulderink F, Cats A. Gastrointestinal telangiectasia as a cause of severe blood loss in systemic sclerosis. Endoscopy 1980; 12: $200-4$.

5 El Omar M M, Jenkins A P, Hollowood K, Baneriee A K, Thompson R P H. Gastric telangiectasias: a rare cause of severe blood loss in CREST syndrome. Postgrad Med $\varsubsetneqq$ 1984; 70: 302-4.

6 Beales I L P. Watermelon stomach in the CREST syndrome. Postgrad Med f 1994; 70: 766-7.

7 Binford R. CREST syndrome with gastrointestinal bleeding. Arch Dermatol 1968; 97: intestinal

8 Marwick T, Kerlin P. Angiodysplasia of the upper gastrointestinal tract. $\mathcal{F}$ Clin Gastroupper gastrointestinal

9 Kolodny M, Baker W G. CREST syndrome with persistent gastrointestinal bleeding. Gastrointest Endosc 1968; 15: 16-17.

10 Papo T, Tusseau F, Piette J C, et al. L'estomac pasteque. Ann Med Intern 1995; 146: 186-8.

\section{Improvement of severe pulmonary hypertension in a patient with SLE}

The development of pulmonary hypertension during the course of connective tissue diseases is associated with a grim prognosis ${ }^{12}$ as no treatment has shown sustained efficacy. Heart-lung transplantation may be undertaken, but experience in patients with systemic disease is limited, costly, and disappointing. ${ }^{2}$ We report on a patient with advanced pulmonary hypertension arising in the course of systemic lupus erythematosus (SLE) successfully treated with vasodilatator and immunosuppressive drugs.

In 1990 SLE was diagnosed in a 22 year old white woman who presented arthralgias, myalgias, pericarditis, Raynaud's phenomenon, hypocomplementaemia, high titre antinuclear antibodies with speckled pattern (anti-Sm, anti-RNP) without DNA or phospholipid antibodies. Low dose prednisone (10 mg/d) was started. Exertional dyspnoea, syncopes and signs of right side heart insufficiency appeared in January 1991, related to precapillary (pulmonary capillary wedge pressure $7 \mathrm{mmHg}$ ) pulmonary hypertension (table). Neither thromboembolism - that is, normal pulmonary angiography, nor interstitial lung disease were present. Heartlung transplantation was considered, but not performed because no donors were available at that time.

In January 1992 corticosteroid treatment (500 mg pulse methylprednisolone for three days, followed by oral prednisone $0.5 \mathrm{mg} / \mathrm{kg} /$ d) in combination with monthly pulse cyclophosphamide $(750 \mathrm{mg}$ ) and mesna were instituted. After two months a dramatic haemodynamic (table) and clinical improvement was observed: the patient had significant resolution of her dyspnoea and was able to walk. Thus in January 1993 prednisone was tapered and pulse cyclophosphamide was given once every three months. At that time the patient returned to work. In September 1994, when the patient had received a total of 20 cyclophosphamide courses over a period of 32 months without any side effects, she decided to stop intravenous treatment, and only low dose prednisone with prazosin was continued. She chose to stop prazosin in July 1995 . The last haemodynamic investigation performed in September 1995 (table) showed an improvement in pulmonary hypertension with both an increase in cardiac index $(+73 \%)$ and a decrease in mean pulmonary artery pressure $(-44 \%)$.

Evolution of haemodynamic findings before (Fanuary 91 and 92) and after two (March 92), 14 (Fune 93), and 20 (September 95) cyclophosphamide infusions

\begin{tabular}{|c|c|c|c|c|c|c|}
\hline & Treatment & $\begin{array}{l}P A P^{\star} \\
(m m H g)\end{array}$ & $\begin{array}{l}\text { Mean PAP } \\
(m m H g)\end{array}$ & $\begin{array}{l}P V R^{\star} \\
(\mathrm{mmHg} / \mathrm{m} \\
\left.\mathrm{min} / \mathrm{m}^{2}\right)\end{array}$ & $\begin{array}{l}C I^{\star} \\
\left(\mathrm{min} / \mathrm{m}^{2}\right)\end{array}$ & $\begin{array}{l}\mathrm{PaO}_{2} \\
(\mathrm{mmHg})\end{array}$ \\
\hline Normal values & & $19(5) / 8(3)$ & $10-20$ & $<5$ & $3-3 \cdot 5$ & $80-100$ \\
\hline January 91 & $\begin{array}{l}\text { Prednisone } 5 \mathrm{mg} / \mathrm{d} \\
+ \text { prazosin } 5 \mathrm{mg} / \mathrm{d}\end{array}$ & $94 / 41$ & 57 & 26 & $2 \cdot 2$ & 60 \\
\hline January 92 & $\begin{array}{l}\text { Prednisone } 30 \mathrm{mg} / \mathrm{d} \\
+ \text { monthly cyclophosphamide }\end{array}$ & $85 / 40$ & 55 & ND & ND & 60 \\
\hline March 92† & $\begin{array}{l}\text { Prednisone } 30 \mathrm{mg} / \mathrm{d} \\
\text { + monthly cyclophosphamide }\end{array}$ & $66 / 27$ & 36 & ND & ND & 78 \\
\hline June 93 & $\begin{array}{l}\text { Prednisone } 15 \mathrm{mg} / \mathrm{d} \\
\text { + quarterly cyclophosphamide } \\
\text { (stopped in September 94) }\end{array}$ & $78 / 28$ & 48 & $13 \cdot 7$ & $3 \cdot 5$ & 82 \\
\hline September 95 & Prednisone $5 \mathrm{mg} / \mathrm{d}$ & $54 / 18$ & 32 & $8 \cdot 5$ & $3 \cdot 8$ & 96 \\
\hline
\end{tabular}

*PAP = pulmonary artery pressure, systolic/diastolic; $\mathrm{PVR}=$ pulmonary vascular resistance; $\mathrm{CI}=$ cardiac index; $\mathrm{PaO}_{2}=$ arterial $\mathrm{O}_{2}$ tension, breathing room air. tPAP calculated with echocardiography. though the initial treatment with vasoSLE and pulmonary hypertension. ${ }^{6}$ JEAN-LUC JAGOT GÉRALD SIMONNEAU

Our patient had several of the variables associated with poor survival rates in patients with pulmonary hypertention ${ }^{3}$ : New York eart Association functional class IV, mean pulmonary arterial pressure, decreased cardiac index. Immunosuppressive treatment -cyclophosphamide infusions once a month months followed by quarterly treatment-resulted in prolonged decrease of pulmonary pressure together with dramatic pulmical improvement. Improvement might ter or could not be attributable to cyclophosphamide only. The association of vasodilatator with immunosuppressive drug treatment might have been helpful, even improvement with immunosuppressive drug reatment have been reported. Corticosteroids alone are rarely efficient. An initial nustained response to high dose patient with mixed connective tissue disease. ${ }^{4}$ Goupille $e t$ al $^{5}$ reported the case of a lupus patient with precapillary pulmonary hyperhigh doses of corticosteroids, with an appreciable follow up of 18 months. ${ }^{5} \mathrm{~A}$ mixed connective tissue disease sequential administration of cyclophosphamide and cyclosporin A over a period of 10 years ${ }^{4}$ Groen et al described a with low dose prednisone and quarterly cyclophosphamide infusions in a woman with

In conclusion, the prolonged and excellent treatment with immunosuppressive drugs associated with vasodilatator agent in precapillary pulmonary hypertension arising in , before considering heart-lung transsuppressive drug treatment in patients with SLE and precapillary pulmonary hypertension are needed.

MARINA KARMOCHKINE
BERTRAND WECHSLER
PIERRE GODEAU
Service de Medécine Interne,
Hôpital de la Pitié-Salpétriere,
Paris, France
FRANÇOIS BRENOT
JEAN-LUC JAGOT
GERALD SIMONNEAU


Service de Pneumologie, Hôpital Antoine Béclère, Clamart, France

Correspondence to: Dr Marina Karmochkine, Service de Médecine Interne, CHU PitiéSalpêtrière, 47/83, Boulevard de l'Hôpital, 75651 Paris Cedex 13, France.

1 Asherson R A, Higenbottam T W, Dinh Xuan A T, Khamashta $M$ A, Hughes $G$ R V. Pulmonary hypertension in a lupus clinic: experience with twenty-four patients. $\mathcal{f}$ Rheumatol 1990;17: 1292-8.

2 Winslow T M, Ossipov M A, Fazio G P, Simonson J S, Redberg R F, Schiller N B. Five-year follow-up study of the prevalence and progression of pulmonary hypertension in systemic lupus erythematosus. Am Heart $\mathcal{f}$ 1995; 129: 510-15.

3 D'Alonzo G E, Barst R J, Ayres S M, et al. Survival in patients with primary pulmonary hypertension: results from a national prospective registry. Ann Intern Med 1991; 115: 343-9.

4 Dahl M, Chalmers A, Wade J, Calverley D, Munt B. Ten year survival of a patient with Munt $B$. Ten year survival of a patient with advanced pulmonary hypertension and mixed connective tissue disease treated with 1992; 19: 1807-9 therapy. $\mathcal{F}$ Rheumatol 1992; 19: 1807-9.

Goupille P, Fauchier L, Babuty D, Fauchier J, Valat J P. Precapillary pulmonary hypertension dramatically improved with high doses of corticosteroids during systemic lupus erythematosus. $f$ Rheumatol 1994; 21: 1976-7.

6 Groen H, Bootsma H, Postma D S, Kallenberg C G M. Primary pulmonary hypertension in a patient with systemic lupus erythematosus: partial improvement with cyclophosphamide. f Rheumatol 1993; 20: 1055-7.

\section{Antibodies to ribosomal P proteins and hepatic damage in undifferentiated CTD}

Ribosomal antibodies were first detected by immunofluorescence in the serum samples of a few patients with systemic lupus erythematosus (SLE) in 1974 by Homberg et al. Presently, it is well known that most ribosomal antibodies recognise a conserved sequence of 22 aa at the carboxy terminus of three ribosomal phosphoproteins $\mathrm{P} 0, \mathrm{P} 1$, and P2 with molecular weights 38,19 , and 17 $\mathrm{kDa}$ respectively (antibodies to ribosomal $\mathrm{P}$ proteins). ${ }^{2}$ These antibodies have been described in about $10 \%$ of patients with SLE and their presence in serum is considered a marker of this disease. Various reports have shown an association between ribosomal antibodies and the development of lupus psychosis, ${ }^{3}{ }^{4}$ whereas others found a correlation with lupus activity. ${ }^{5}$ Recently, an association between antibodies to ribosomal $P$ proteins and liver or renal complications, or both, in SLE has been suggested. ${ }^{67} \mathrm{We}$ would like to comment on an interesting case in which a relation between the development of liver disease and the titres of antibodies to ribosomal $\mathbf{P}$ proteins was found in a patient with undifferentiated connective tissue disease.

In March 1992 a 9 year old girl was referred to Asturias Central Hospital with high fever, polyarthritis, oral ulcers, Raynaud's phenomenon, generalised hand swelling, and conjunctivitis. Laboratory studies showed a normal total and differential white cell count, an erythrocyte sedimentation rate of $88 \mathrm{~mm} / 1 \mathrm{st} \mathrm{h}$, and serum $\mathrm{C}$ reactive protein of $5.1 \mathrm{mg} / 1$ (normal values (NV) $<6 \mathrm{mg} / \mathrm{l}$ ). Blood chemistry showed slightly raised levels of the liver enzymes aspartate aminotransferase (AST) and alanine aminotransferase (ALT) (fig 1). Immunological studies disclosed increased levels of serum IgG to $24 \cdot 4 \mathrm{~g} / 1$ (NV 5.6-17.6 $\mathrm{g} / \mathrm{l})$, a rheumatoid factor test of $126 \mathrm{IU} / \mathrm{ml}$ (NV $<30 \mathrm{IU} / \mathrm{ml}$ ), and normal complement levels. Immunofluorescence on Hep-2 cells showed positive staining of the cytoplasm and nucleoli; no other nuclear staining patterns were observed. The patient's serum strongly stained the cytoplasm of the chief cells of rat stomach, which is characteristic of the presence of ribosomal antibodies. The serum was titrated for the presence of ribosomal and nucleolar antibodies on rat tissue sections (liver, kidney, and stomach) (fig 1). At the starting dilution (1/40) all normal serum samples were negative. The Western blot test, using rat ribosomes as a source of antigen, disclosed the presence of antibodies reacting with a $38 \mathrm{kDa}$ ribosomal $\mathrm{P0}$ protein (ribosomal antibodies) (fig 2). Tests for other autoantibodies (dsDNA, SS-A, SS-B, Sm, and $n R N P$ ) were negative.

Despite the presence of antibodies to ribosomal $\mathbf{P}$ protein, which is considered as a marker of SLE, the diagnosis was undifferentiated connective tissue disease because the patient did not fulfil the American Rheumatism Association criteria for the diagnosis of SLE. She was treated with prednisolone $(20 \mathrm{mg} /$ day $)$. The acute manifestations resolved rapidly, and the patient left hospital three weeks later in a good condition. The dose of prednisolone was tapered gradually.

In February 1993, while the patient was receiving a daily dose of $2 \mathrm{mg}$ of prednisolone and $500 \mathrm{mg}$ of the non-steroidal antiinflammatory drug naproxen, a high increase in the seric concentration of the liver enzymes was observed (AST $334 \mathrm{U} / \mathrm{l}$, ALT $438 \mathrm{U} / \mathrm{l}$ $\mathrm{NV}<31 \mathrm{U} / \mathrm{l}$ for both enzymes). She had no hepatomegaly and serological tests for the Epstein-Barr virus, cytomegalovirus, and viral hepatitis were all negative. The increased liver enzyme levels were accompanied by a parallel increase in the titres of cytoplasmic and nucleolar antibodies. Owing

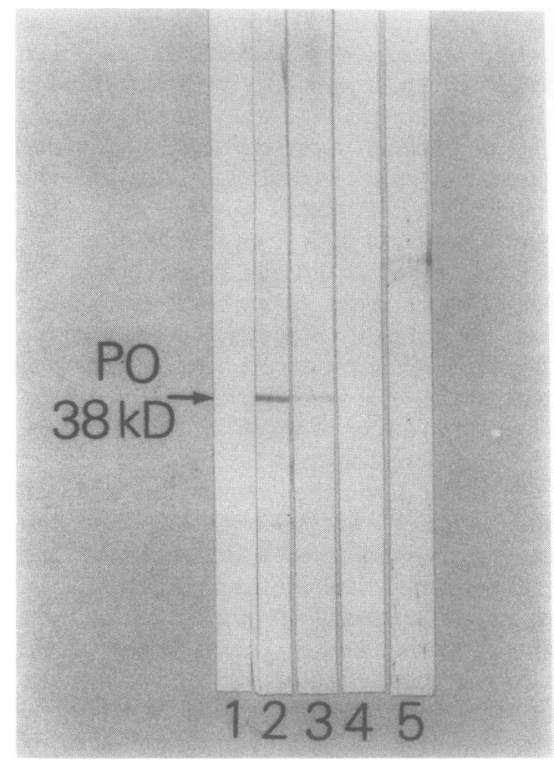

Figure 2 Recognition of antibodies against PO ribosomal protein by immunoblotting. Lane $1=$ negative control serum; lanes 2 and $3=$ samples obtained from the patient in February 1993 and fuly 1995, respectively; lanes 4 and $5=$ samples containing mitochondrial antibodies.

to the possibility of drug induced live damage, naproxen was discontinued and the dose of steroids reduced to $1 \mathrm{mg}$ on alternate days. However, the levels of liver enzymes and the titres of ribosomal antibodies and nucleolar antibodies remained abnormally high.

In April 1994 the patient was readmitted with an acute episode of severe asymmetrical polyarthritis. High dose prednisolone treatment was reintroduced $(0.75 \mathrm{mg} / \mathrm{kg}$ daily), and treatment with antimalarial drugs (3 $\mathrm{mg} / \mathrm{kg}$ daily) was started. Interestingly, despite the relapsing of her articular process the titre of autoantibodies decreased as well as the levels of liver enzymes, which normalised by June 1994. In September 1994
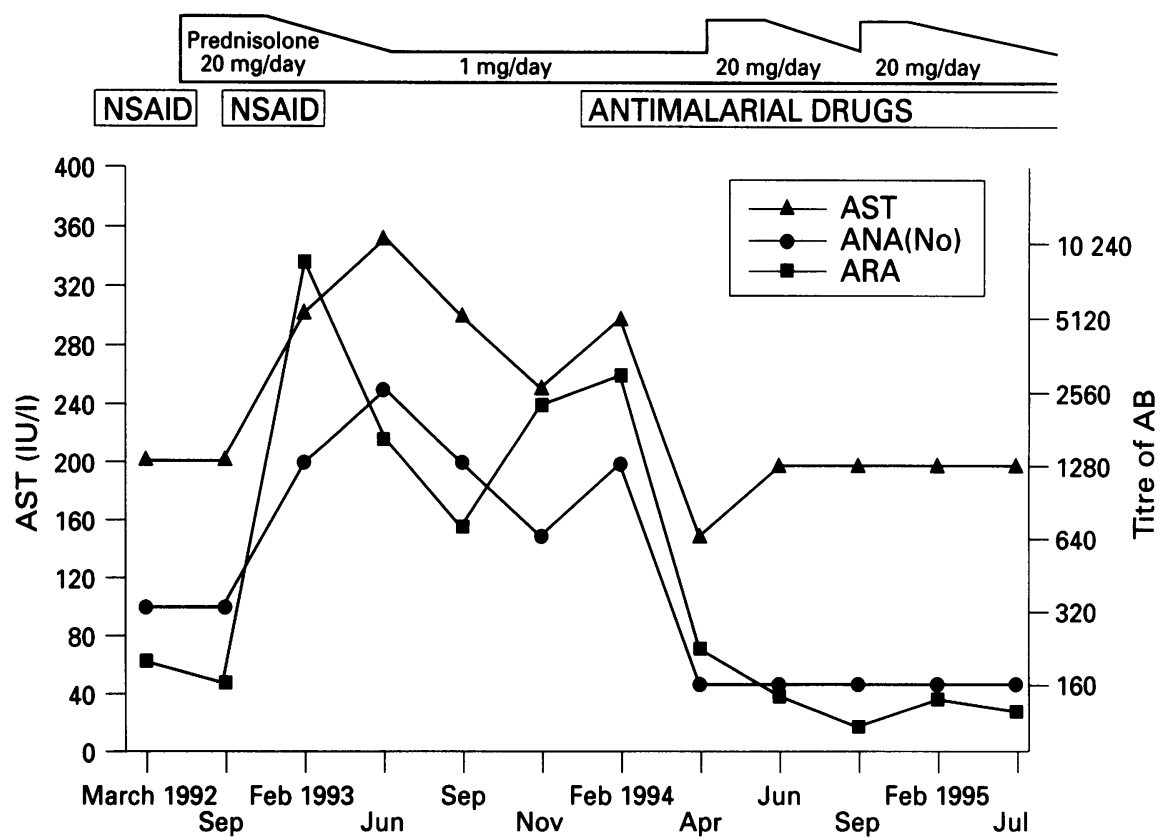

Figure 1 Correlation between seric concentration of liver enzymes and titres of ribosomal antibodies. $A S T=$ aspartate aminotransferase; $A N A(N o)=$ antinucleolar antibodies. $A R A=$ antiribosomal antibodies. Alanine aminotransferase levels ran parallel to those of AST (data not shown). 